\title{
Protective effect of injectable iron on cadmium- induced anemia in rats
}

\author{
Ghada A. Taqa \\ Jawnaa K. Mamdoh \\ Department of Dental Basic Sciences / College of Dentistry. \\ University of Mosul
}

\section{Received}

18 / 02 / 2009
Accepted

15 / 07 / 2009

\section{الخلاصة}

بسعى البحث الحالي لدراسة التأثير الوقائي للحديد من فقر الدم المحدث في الجرذان

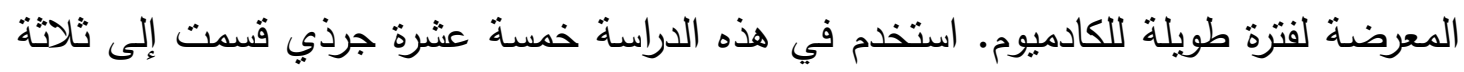

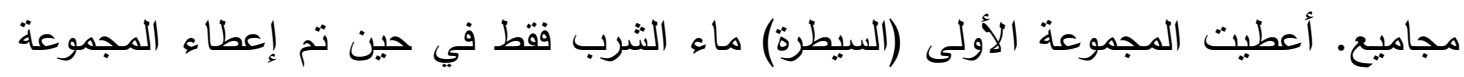

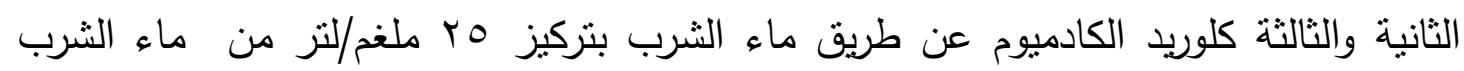

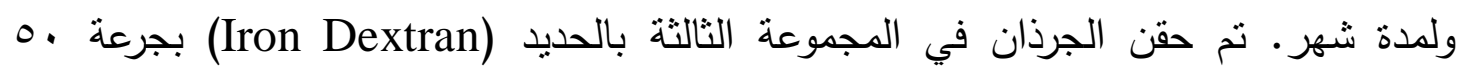
ملغم/كغم في الخلب بين يوم وأخر لأربع مرات بالإضافة إلى وجود الكادميوم في ماء الثرب.

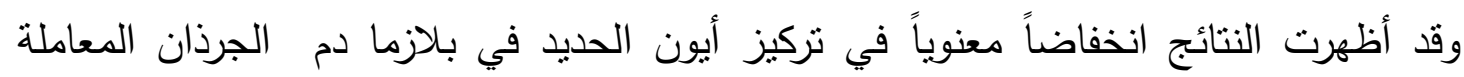

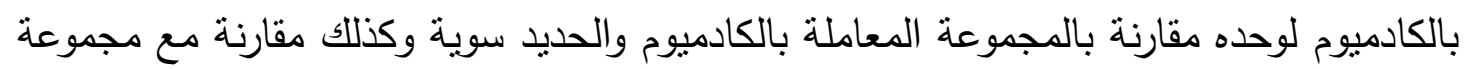

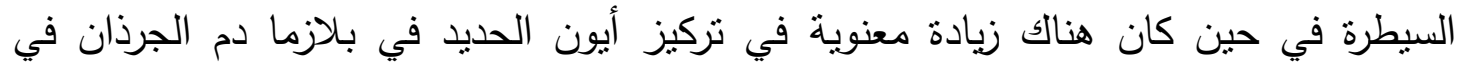

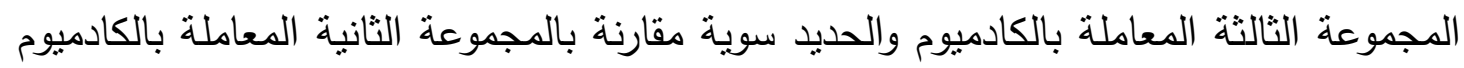

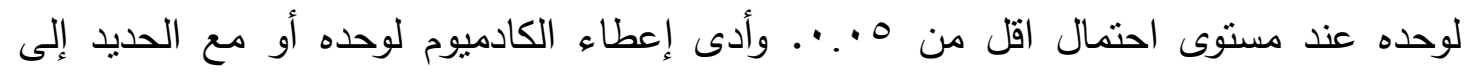

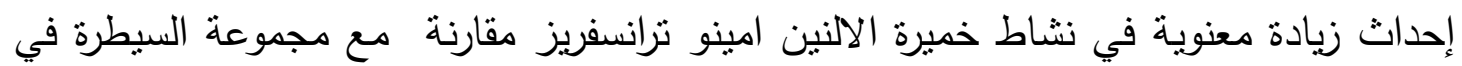

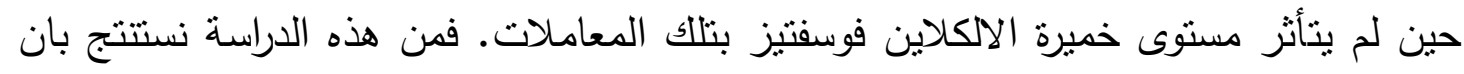

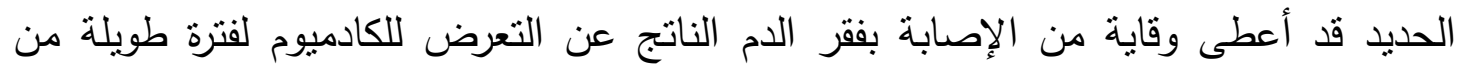

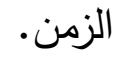

\section{Abstract}

The current paper studied, the protective effect of iron on anemia induced by Cadmium $(\mathrm{Cd})$. Fifteen male albino rats selected in this study divided into three groups, first group as control, $2^{\text {nd }}$ and $3^{\text {rd }}$ groups 
received oral $\mathrm{CdCl}_{2} 25 \mathrm{mg} / \mathrm{L}$ mixed with drinking water for one month. Third group treated four dosage of injected iron (iron Dextran) at 50 $\mathrm{mg} / \mathrm{kg}$ intraperitonially in addition to cadmium drinking water. The result of this study showed a significant decreased of iron concentration in plasma of $\mathrm{Cd}$ treated group but there is a significant increase in iron concentration in $3^{\text {rd }}$ group compared to $2^{\text {nd }}$ group $p<0.05$ while there is a significant elevated with alanine aminotransferase enzyme in $2^{\text {nd }}$ and $3^{\text {rd }}$ group in comparing to control group. Alkaline phosphatase enzyme no change. Conclusions: this study concluded that iron supplement is prevent anemia induced by long exposure to cadmium.

\section{Introduction}

Cadmium $(\mathrm{Cd})$ is a wide spread industrial pollutant causing acute and chronic poisoning in human and animals .It is known to be one of the most toxic heavy metals. This toxic element can enter the metabolic pathway of some essential trace element including copper, zinc, iron, manganese, selenium and calcium by competing for ligands in biological system (1). Cd is a toxic heavy metals can enter the diet of farm animals by variety of exposure rout (diet and water) $(2,3,4,5)$, One of the target organs which could be affected is the erythrocytes (6).

Anemia is commonly induced by chronic cadmium intoxication, which could be due to many proposed mechanisms. One of these mechanisms is intravascular hemolysis which can occur at the early stage of $\mathrm{Cd}$ exposure to the direct damaging effect on erythrocytes. This lead to produce a condition of microcytic hypochromic anemia and a state of iron deficiency (7). The significantly decrease of iron concentration in the body after exposure to $\mathrm{Cd}$, result in decrease iron concentration in the liver, spleen and other tissues $(8,9)$. The aim of the present study is to examine the protective effect of iron injectable in reversing the effect of cadmium induce anemia in rats.

\section{Materials and Methods}

Fifteen male albino rats (10 weeks) weighing between (200-250) $\mathrm{gm}$. They were housed under laboratory conditions at a temperature of $(22 \pm 2) \mathrm{C}^{\circ}$ with a natural light/dark cycle, and food was available.

Randomly selected animals were assigned to three experimental groups (5 rats/group). The first group (control) received drinking water only, The $2^{\text {nd }}$ group received cadmium - water $\left(\mathrm{Cd}-\mathrm{H}_{2} \mathrm{O}\right)$ for 4 weeks orally. $\left(\mathrm{Cd}-\mathrm{H}_{2} \mathrm{O}\right)$ concentrate was prepared at $6.3 \mathrm{ppm} \mathrm{Cd}$ concentration in water $\left(25 \mathrm{mg} \mathrm{CdCl}_{2}\right.$ in one liter $\left.\mathrm{H}_{2} \mathrm{O}\right)$. The concentration of $\mathrm{Cd}$ depended on Petersson (10). $3^{\text {rd }}$ Group was received iron at $50 \mathrm{mg} / \mathrm{kg}$ intraperitonially during $1^{\text {st }}, 3^{\text {rd }}, 5^{\text {th }}, 7^{\text {th }}$ days in addition to $\left(\mathrm{Cd}-\mathrm{H}_{2} \mathrm{O}\right)$. All experimental animal were scarified at day 30 of experiment, and blood 
sample were collected in heparinized tube, plasma were obtained and used for assay iron by (Iron colorimetric kit, Biomaghreb), alanine aminotransferase enzyme (ALT kit, Bio Merieuxsa, France) and alkaline phosphtase enzyme (ALP kit, Syrbio, Syria).

The data were expressed as mean $\pm \mathrm{SE}$, difference between three experimental groups were statistically analyzed by analysis of variance followed by the least significant difference test. The level of significance was at $\mathrm{p}<0.05$.

\section{Results}

In the present study exposure to $\mathrm{Cd}$ in drinking water for one month had lead to a significant decrease in iron concentration of plasma in $2^{\text {nd }}$ group compared to control group (figure 1). The administration of iron at $50 \mathrm{mg} / \mathrm{kg}$ with $\mathrm{Cd}$ was significantly increase the concentration of iron in $3^{\text {rd }}$ group compared with $2^{\text {nd }}$ group which treated by $\mathrm{Cd}$ alone. Non significant difference was found between control and $3^{\text {rd }}$ groups (figure 1).

The alanine aminotransferase enzyme activity was significantly increased in $2^{\text {nd }}$ and $3^{\text {rd }}$ group in comparison to control group but alkaline phosphatase enzyme was non significantly affected by cadmium (table 1).

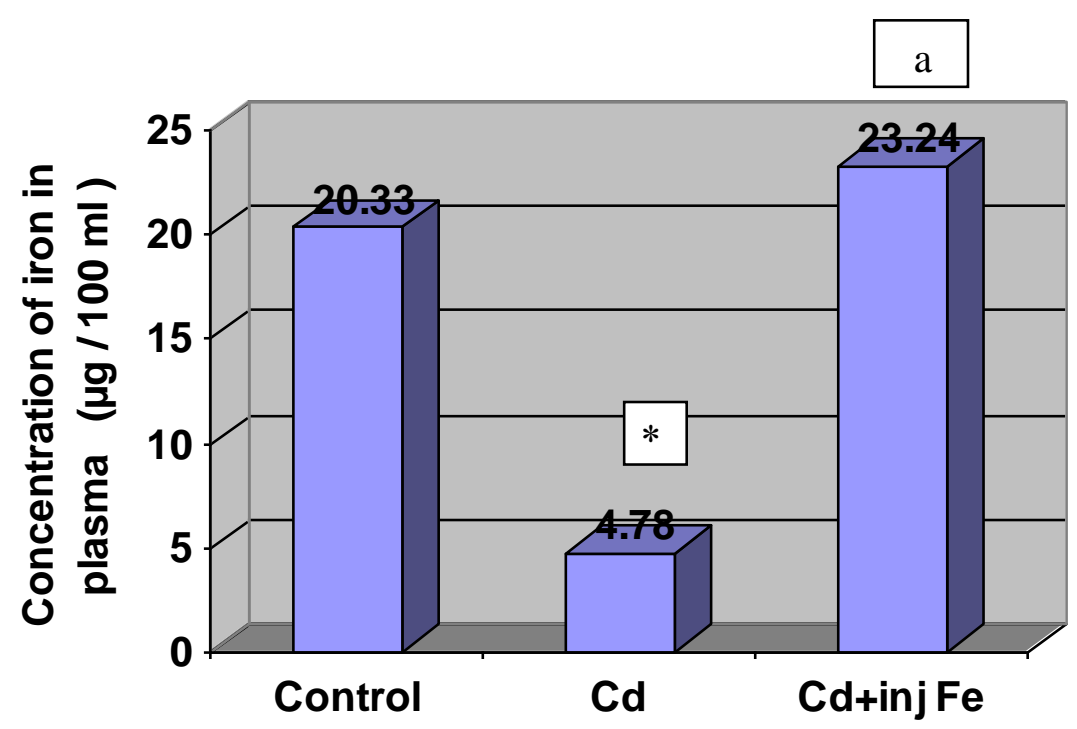

Figure(1): Effect of $\mathrm{Cd},(\mathrm{Cd}+$ iron $)$ combination on iron concentration in the plasma of rats after one month of treatment

- value are mean \pm SE 5 rats /group .

* Significantly different from the control group. $\mathrm{P}<0.05$.

a. Significantly different from $\mathrm{Cd}$ alone treated. $\mathrm{P}<0.05$ 
Table (1): Effect of $\mathrm{Cd},(\mathrm{Cd}+$ iron) combination on alanine aminotransferase enzyme and alkaline phosphatase enzyme in plasma of rats after one month of treatment

\begin{tabular}{|c|c|c|c|}
\hline \multicolumn{4}{|c|}{ Treatment } \\
\cline { 2 - 4 } & Control & Cd & $\mathrm{Cd}+\mathrm{Fe}$ \\
\hline ALT ( unit /liter) & $9.2 \pm 1.3$ & $16.9 \pm 1.8^{*}$ & $18.6+0.7 *$ \\
\hline ALP (unit/liter) & $179.9 \pm 17.3$ & $189.4_{-}+9.7$ & $180.1 \pm 12.9$ \\
\hline
\end{tabular}

- value are mean \pm SE 5 rats /group .

* Significantly different from the control group. $\mathrm{P}<0.05$.

ALT: alanine aminotransferase enzyme.

ALP: alkaline phosphatase enzyme.

\section{Discussion}

In the present study rats exposed to cadmium showed decrease in iron concentration of blood. Iron depletion has been recognized as one of the mechanism of $\mathrm{Cd}$ - induce anemia $(7,10)$ because $\mathrm{Cd}$ accumulate in erythrocytes affected membrane cytoskeleton and decreases cell deformability, and these cells are trapped and destroyed in spleen. Iron deficiency can be detected in animals after an oral exposure to $\mathrm{Cd}$, which compete with iron for absorption in the intestines then cadmium bind with membrane of red blood cells (11). Cd distribution to the liver and subsequently stimulate the synthesis of metallothionin (MT) which binds Cd forming Cd- MT complex and reactive oxygen species $(12,13,14)$. The Cd- MT is transport to the blood and cause destruction of the red blood cell and this lead to anemia $(15,16)$.

In the present study, injectable iron intraperitonial in first week of exposure to $\mathrm{Cd}$ cause significantly increase in iron concentration in group $3^{\text {rd }}$ in comparison to group $2^{\text {nd }}$ and the value of iron was return to normal value. This result was in agreement with other studies that suggested adequate dietary iron supplement reduce Cd retention in the body. Iron and $\mathrm{Cd}$ compete on same sensitive site in the gastrointestinal tract, or may be due to $\mathrm{Cd}$ inhibit absorption of iron at low to the normal levels of dietary intake iron but in high levels supplement of iron, $\mathrm{Cd}$ are absorb by other non competitive mechanism $(17,18)$.

In $2^{\text {nd }}$ and $3^{\text {rd }}$ group showed that the alanine aminotransferase enzyme was increased probably due to $\mathrm{Cd}$ induce liver injury and damage. This finding is in agreement with other studies that suggest the administration of $\mathrm{Cd}$ increase the level of alanine aminotransferase enzyme. (19, 20). It was suggested that $\mathrm{Cd}$ causes liver injury and damage $(21,22)$. because $\mathrm{Cd}$ distribution to the liver and stimulate to synthesis of Cd-MT complex and increase the level of alanine aminotransferase in the blood $(12,13)$. Alkaline phosphatase enzyme was not affected by $\mathrm{Cd}$ exposure. 


\section{Conclusion}

From this results the Parental administration of iron intraperitonally for rats exposure to Cadmium for long period in drinking water produced a protective effect from anemia induce by Cadmium. Iron supplementary found to be an essential to overcome anemia induced by Cadmium toxicity.

\section{Reference}

1) Goering, P. L., Waalkes $M P$, and Klaassen $C$ D. Toxicology of cadmium. In Toxicology of metal. Bioch Aspect, Expier. Pharm. New York. Vol. 115: 189- 213. (1995).

2) National Research council (NCR). Mineral tolerance of Domestic Animals. National Academy of sciences. Washington, D.C., P.P: 93 - 130. (1980).

3) WHO. Cadmium Environmental Health Criteria, 134, world Health Organization, Geneva., PP: 17 - 273. (1992 a).

4) WHO. Cadmium Environmental Aspects . Environmental Health Criteria, 135, World Health Criteria, 135, World Health Organization, PP. 13 - 154. (1992 b).

5) Kishor B. R., Shahnaz. EJ. Timothy. J. P, Robert J. S. Iron and cadmium uptake by duodenum of hypotransferrin mice. Biometal. Vol. 19, issue 5, P: 547 - 53. (2006).

6) Jurczuk M, Brzoska, M. M., Rogalska, J and MoninszkoJakonink. J. Iron body status rats chronically exposed to cadmium and ethanol. Medical Council on alcohol, Vol. 38, PP. $202-207$. (2003).

7) Sarkar, S., Yadar, P. and Bhatnagar, D. Lipid peroxidative damage on cadmium exposure and alteration in antioxidant system in rat erythrocytes: a study with relation to time. Biometals. 11(2): 153 - 7. (1998).

8) Oishi, S., Nakagawa, J.- I. and O. M. Effects of cadmium administration on the endogenous metal balance in rats. Biological Trace Element Research , 257 - 278. (2000).

9) Min, k.s., Iwata N., Tetsutikawahara, N., Onosaka, s., Tanaka, K. Effect of hemolytic and iron -deficiency anemia on intestinal absorption, and tissue accumulation of cadmium. Toxicol Lett, 10, 179 (1): 48- 52. (2008)

10) Petersson, G. K. Lactational transfer of cadmium in rodents- CNS effect in the offspring. Doctor's dissertation. Swedish University of Agricultural Sciences, Sweden, (2003).

11) Horiquchi, H. Anemia induce by cadmium intoxication. Nippon Eiseiqaku Zasshi, 62(3): 888-904. (2007). 
12) Elsenhans B, Kolb K, Schumann K, Forth W. The longitudinal distribution of cadmium, zinc, copper, iron, and metallothionein in the small intestinal mucosa of rats after administration of cadmium chloride. Biol Trac Elem Res, 41: 31 - 46. (1994).

13) Reddy CS, Mohammad F K, Ganjam V K, Martion M A, Brown E M. Mobilization of tissue cadminm in mice and claves and reversal of cadmium induced tissue damage in calves by zinc. Bull Environ Contam Toxiccol, 39: 350 -357, (1987).

14) Simpkins, C., Lloyd $T$, and Balder. Metallothionein.- induced in mitochondrial inner membrane permeability, T. surg. Res., 75:3034. (1998)

15) Bauman, J. W, Liu, J and Klaassen, C.D. Production of metallothionein and heat-shock protein in response to metals. Fundam. Appl. Toxicol., 21: 15 - 22. (1993).

16) Sarkar, S. Yadar, P. and Bhatnagar, D. Cadmium-induce lipid peroxidation and the status antioxidant system in rat tissue. J. Trace. Elem. Med. Biol., 11 (1): 8 - 13. (1995).

17) Schumann K, Friebel P, Schmolk G. Elsenhans B. State of iron replation and cadmium tissue accumulation as a function of growth in young rats after oral cadmium exposure. Arch Environ Contam. Toxical., 31:423-7. (1996).

18) Growe A, Morgan E H. Effect of dietary cadmium on iron metabolism in growing rats. Toxical APPl Pharmacol., 145:136 46. (1997).

19) El-Demerdash, F. M Yousef, M, I, Kedwang, F. S. and Baghdadi, H. H Cadmium induced change in lipid peroxidation - blood hematology, biochemical parameters and semen quality of male rats: Protective role of vitamin E and beta -carotene food. Chem, Toxical, 42 (10): 1563-71. (2004).

20) Egwurugwu, J. N, Ufaro C. S. Abanobi, O. C, Nwokocha, C. R. Effect of ginger (Zingiber officinale) on cadmium toxicity. African J Biotechnology., 6: 2078- 2082. (2007).

21) Zikic, R. V, Stajn. A. S., Pavlovic, S. Z. Ogniganovic, B. I. and Saicic, Z. S. Activities of super oxide dismutase and catalase in erythrocytes and plasma transaminase of gold fish (carassius auratus gibelio bloch) exposed to cadmium. Physiol. Res. 50: 105111. (2001)

22) Klaassen, C. D, Liu, J. Induction of Metallothionein as an adaptive mechanism affecting the magnitude and progression of toxicological injury. Environ. Heath Perspect., 106:297-300. (1998). 